\title{
The Effect of Cooperative Learning Type Teams Games Tournament (TGT) on Creativity and Comprehension the Student's Concept in Mathematics Learning
}

\section{Anisa Ramadiana, Akhsanul In'am, Adi Slamet Kusumawardana}

\author{
Mathematics Education Study Program \\ Faculty of Teacher Training and Education \\ University of Muhammadiyah Malang \\ ramadiananisa@gmail.com
}

\begin{abstract}
This study aims to effect of the TGT learning model on student's creativity and comprehension of concepts in mathematics learning. This study used quasi-experimental research. The population in this study were 256 students of class VIII SMP YPPSB. The research sample was obtained in class VIII-H of 32 students as the experimental class and class VIII-D with total of the students were 31 students as the control class. The test used to analyze the research data was the Independent Sample T-test on the posttest results. The results of the study showed that creativity and comprehension of concepts using the TGT learning model was better than the class that used conventional learning. The average creativity used the TGT learning model $t_{\text {count }}=4.080$ and the average comprehension of the concept of $t_{\text {count }}=11.012$ with $t_{\text {table }}=2.00$ which means $t_{\text {count }}>t_{\text {table. }}$. Thus, the TGT type learning model has a significant influence on student's creativity and comprehension of concepts in mathematics learning.
\end{abstract}

Keywords: Cooperative Learning, TGT, Creativity, Comprehension of concepts

\section{INTRODUCTION}

Educational problems can occur in various countries in both developed and developing countries (Retnawati et al., 2017). The availability of sophisticated technology, adequate facilities and infrastructure, but it was not not rule out the possibility that developed countries do not have problems in education as well as in developing countries. Indonesia as a developing country has various kinds of educational problems in an effort to improve the intelligence of its people (Baleendah \& Rodiah, 2017). The demands of increasingly advanced scientific and technological developments require to create innovative learning in overcoming these educational problems (Onal, 2017).

Various ways have been carried out by the government in an effort to improve the quality of education in Indonesia. All efforts was made, namely by holding curriculum changes, changing ministers of education, holding training activities for teachers, completing facilities and infrastructure in schools to increase the level of difficulty in national examinations (Raharjo, 2012). The effort was made to create a teacher who has pedagogical, professional, personal and social competencies (Agung \& Yufridawati, 2013). Educators who have competence in accordance with expected can educate, teach, guide, direct, train, assess, and evaluate students to create generations that are needed in the future (Basri, 2013).

Learning in Indonesia consists of various fields of science, one of was mathematics. Mathematics was one of the fields of study offered by formal education in Indonesia and the world. Considering the importance of mathematics for life, mathematics was one of the lessons that must be given at every level of basic education to university. One science that was very 
useful in everyday life and closely related to calculations (Sanusi, Suprapto, \& Apriandi, 2015). Students could practice using their minds logically, analytically, systematically, critically and creatively. The student have the ability to cooperate in dealing with various problems and are able to utilize the information they receive, namely by learning mathematics (Hakim \& Windayana, 2016). The learning of mathematics at this time has been facilitated by the various applications of learning models in schools.

Learning models was needed to optimize, improve and develop student's creativity. One effort to improve student's creativity and comprehension is by using learning models that better support student's activities in comprehension a subject matter. Selection of the right learning model in order to stimulate students to play an active role in learning. An effective learning model can improve student creativity is a cooperative learning model, because in the cooperative learning model there is an element or syntax that requires students to be able to cooperate, discussion and group presentations (Ainun, 2015).

Cooperative learning was learning through small groups generally consisting of 4-6 students to be able to discuss, interact, solve problems, and carry out their obligations in groups according to their respective duties to achieve common goals (Purnomo, 2011). Cooperative learning encouraged students to be active and give mutual support to fellow group members to solve the problems given. Completion of the task here was not only in terms of answering questions, but encourages students to reason based on their knowledge in comprehension the material being studied (Prabawanti, et al, 2013). Cooperative learning was the learning based on comprehension constructivism (Trianto, 2012).

Constructivist approaches in learning mathematics can be carried out if students actively absorb new information, experience and build their own comprehension. One of the main objectives of mathematics education was to help students think mathematically (Ding, et al., 2007) and this can be achieved by facilitating problem solving in cooperative learning environments (Tarim, 2009). Based on this, cooperative learning activities such as group work and discussion in terms of developing the ability to use and apply knowledge, reasoning and cognitive comprehension are felt to be more important than memorizing facts and mastering routine skills in mathematics learning.

Various reasons for the causes of cooperative learning are able to enter the norm in the learning process. In addition to the existence of tangible evidence of its success, in the present society in the world of education were increasingly aware of the importance of training students to think, solve problems, and combine their abilities and expertise. Even though cooperative learning will work well in a class with even abilities, on the other hand, classes with diverse student abilities require more cooperative learning (Isjoni, 2016).

One of the cooperative learning models, namely the TGT type, focuses on students in the learning process. All students in each group are required to try to understand and master the material being taught and are always active when group work so that when appointed to present their answers they can contribute to contributing scores to their groups (Marnih, 2016). Another advantage of this learning model in the learning process emphasizes the existence of a competition that was done by comparing members' abilities in a form of tournament or match. This tournament prepares students to have the courage to compete, can cooperate in groups and have the ability to compete (Tiya, 2013).

The problem that occurs in math class was the teacher dont use various learning models. Learning at this time the teacher still adheres to conventional learning namely ordinary learning using the expository method, discussion and assignment. The expository method was easy to implement because it only relies on the voice of the teacher who explains in front of the class and does not require much equipment. The expository method make difficulties to the teachers 
to control the extent to the students to understand mathematics learning (Mudlofir \& Rusydiyah, 2017). It makes the teacher feeling difficult to know the extent to which learning objectives have been achieved. This is felt by students to be very boring because learning feels very monotonous (Hernawan, 2017).

Learning was currently teacher centered in the class, and it isn't much involves students in the learning process that is when working on the problem in front of the class. Based on that, the lack of involvement of students so that they can play an active role in the learning process. As a result, teachers cannot combine student's creativity in learning, because there was no opportunity or place for students to express their creativity (Windayana, 2010). Creativity was needed in learning mathematics, creativity will provide opportunities for students to develop abilities in solving mathematical problems (Mann, 2009). The teacher's strategy in applying the right learning model can improve student creativity compared to ordinary learning that does not require creativity. The existence of these strategies can foster student creativity if given different treatments (Sharma, 2014).

Creativity will be seen if the students can find several possibilities and expectations and can find new ways and strategies in solving a problem (Subur, 2013). The results of creative thinking refer to creativity because creative thinking can be said to be a process used when students can bring up new ideas (Richardo et al. 2014). One of the goals of mathematics learning is to develop student's creativity.

The TGT cooperative learning model can be a place to develop creativity. The development of creativity using the TGT type learning model plays a role in increasing comprehension of mathematical concepts. Creativity as the ability to create something new, and provide new ideas that can be applied in problem-solving. Creativity can improve understanding of mathematical concepts, encourage initiative and creation, so that understanding concept can be achieved (Oktavia, 2015). If the students have good creativity, students will try various efforts to solve problems in a way or technique that is different from the others. This means that students not only use the reference given by the teacher. The students used acquired knowledge to learn with their groups when applying the TGT cooperative learning model.

The indicators of creativity in problem-solving can be interpreted by fluency, flexibility, originality, and elaboration (Purnomo, 2011). Fluent thinking skills can be seen from the ability of the students to think fluently so that they will produce answers or can solve problems quickly and precisely. Flexibility thinking skills can be seen from the ability of students to produce ideas, answers, and questions that vary or can see problems from different points of view. Original thinking skills can be seen from the ability of students to discover or describe something new and unique from their own thinking. Detailed skills or elaboration can be seen from the ability of students to develop an idea or answer by doing steps in detail (Munandar, 2004).

The ability to comprehension of concepts consists of several indicators namely first, restating a concept; second, classifying the objects according to certain characteristics (according to the concept); third, giving an examples and non examples of a concept; fourth, presenting the concepts in various forms of mathematical representation; fifth, develop necessary requirements or sufficient requirements from a concept; sixth, using certain procedures or operations; seventh, applying a problem-solving algorithm or algorithm (Fadjar, 2009). Based on the explanation, the writer wants to examine more deeply the presence/absence of the influence of the TGT cooperative learning model on creativity and comprehension of student's concepts in mathematics learning. 


\section{RESEARCH METHOD}

The research approach used was a quantitative approach with a type of quasiexperimental research. The population in this study were 256 students of SMP YPPSB Sangatta Utara. The research samples were class VIII-H as the experimental class and class VIII-D as the control class. The number of students in class VIII-H consisted of 32 students and class VIII-D consisted of 31 students.

The data collection technique used by researchers to obtain the data needed in the study through a descriptive test to measure student's creativity and comprehension of concepts. The description test consists of 4 items which were arranged based on indicators of creativity and comprehension of concepts. The question number one was used to measure indicators of creativity and to measure indicators of comprehension of concepts, namely restating a concept and giving examples and not examples of concepts. The question number two was used to measure indicators of creativity and to measure indicators of comprehension of concepts, namely presenting concepts in various forms of representation. The question number three was used to measure indicators of creativity and to measure indicators of comprehension of concepts, namely presenting concepts in various forms of representation, using certain procedures or operations, and applying problem-solving algorithms or algorithms. The question number four was used to measure indicators of creativity and to measure indicators of comprehension of concepts, namely developing necessary requirements or sufficient requirements from a concept, using certain procedures or operations, and applying problemsolving algorithms or algorithms.

The data analysis techniques used statistical methods. The prerequisite test to test the hypothesis was the normality test using the Kolmogorov-Smirnov test and homogeneity test using the Levene test. After the normality test done by obtaining normal distributed data and homogeneity test by obtaining data that has homogeneous/identical variance, then the hypothesis was tested, namely the analysis technique of the Independent Sample T-Test using the t-test.

\section{RESULT AND DISCUSSION}

The normality test was carried out to require that the data to be analyzed includes normal distribution. The data used was posttest scores based on creativity and comprehension of concepts. Tests were carried out using SPSS 21 with the Kolmogorov-smirnov normality test. The results of the normality test was presented in the following table.

Table 1. The result of Normality Test Creativity and Comprehension of Concepts

\begin{tabular}{ccccc}
\hline No. & Data & $\begin{array}{c}\text { Sig. } \\
\text { Experimental } \\
\text { class }\end{array}$ & $\begin{array}{c}\text { Sig. } \\
\text { Control } \\
\text { Class }\end{array}$ & Description \\
\hline 1. & Creativity & 0,070 & 0,064 & $\begin{array}{c}\text { Data } \\
\text { normally } \\
\text { distributed }\end{array}$ \\
\hline 2. & $\begin{array}{c}\text { Comprehension } \\
\text { of concepts }\end{array}$ & 0,082 & 0,073 & $\begin{array}{c}\text { Data } \\
\text { normally } \\
\text { distributed }\end{array}$ \\
\hline
\end{tabular}


Based on the table, the significance value of creativity of the experimental class was 0.070 and the significance value of creativity of the control class was 0.064 . Both significance values were more than 0.05 , so $\mathrm{H}_{0}$ was accepted so that it can be concluded that the creativity of students in the experimental class and the control class was normally distributed. While the significance value for comprehension the student's concept in the experimental class was 0.082 and the significance value for comprehension the student's concept of the control class was 0.073. Both significances values were more than 0.05 , so $\mathrm{H}_{0}$ was accepted so that it can be concluded that comprehension the concepts of students in the experimental class and the control class was normally distributed.

The homogeneity test was carried out as an analysis prerequisite test to find out whether homogeneous variants of the experimental class and the control class. Tests were carried out using SPSS 21 using Levene Test.

Table 2. The result of Homogeneity Test Creativity and Comprehension of Concepts

\begin{tabular}{ccccc}
\hline No. & Data & $\boldsymbol{F}$ & Sig. & Description \\
\hline 1. & Creativity & 0,487 & 0,488 & $\begin{array}{c}\text { homogeneous } \\
\text { variants/identical }\end{array}$ \\
\hline 2. & $\begin{array}{c}\text { Comprehension } \\
\text { of concepts }\end{array}$ & 0,280 & 0,598 & $\begin{array}{c}\text { homogeneous } \\
\text { variants/identical }\end{array}$ \\
\hline
\end{tabular}

Based on the table, the calculated significance value for student creativity was 0.488 . The significance value was more than 0.05 , so $\mathrm{H}_{0}$ was accepted so that it can be concluded that the value of the creativity of the experimental class students and control class was homogeneous/identical. While the significance value for comprehension the student's concept was 0.598 . The significance value was more than 0.05 , so $\mathrm{H}_{0}$ was accepted so that it can be concluded that the value of comprehension the student's concept of the experimental class students and control class was homogeneous/identical.

Hypothesis testing was carried out after the analysis prerequisite test has been fulfilled. In this study, the normality test and homogeneity test have been fulfilled, the researcher could test the hypothesis. Testing the hypothesis using the Independent Sample T-Test, this test was used to test the differences in the average value of creativity and comprehension the student's concept from both classes, with the following hypothesis:

a. The first hypothesis

$\mathrm{H}_{0}$ accepted : The average score of the two classes was the same (there was no significant positive effect on the implementation of the TGT type learning model to creativity).

$\mathrm{H}_{1}$ accepted : The average score of the two classes was different (there was a significant positive effect of the implementation of the TGT type learning model on creativity).

b. Second hypothesis

$\mathrm{H}_{0}$ accepted : The average score of the two classes was the same (there was no significant positive effect on the implementation of the TGT type learning model to comprehension of concept).

$\mathrm{H}_{1}$ accepted : The average score of the two classes was different (there was a significant positive effect on the implementation of the TGT type learning model to comprehension of concept). 
Table 3. The result of Hypothesis Test

\begin{tabular}{|c|c|c|c|c|c|c|c|c|}
\hline & & \multicolumn{7}{|c|}{ T-test for Equality of Means } \\
\hline & & \multirow{2}{*}{$\mathbf{T}_{\text {count }}$} & \multirow{2}{*}{ f } & \multirow{2}{*}{$\begin{array}{l}\text { Sig. }(2- \\
\text { tailed })\end{array}$} & \multirow{2}{*}{$\begin{array}{l}\text { Mean } \\
\text { Difference }\end{array}$} & \multirow{2}{*}{$\begin{array}{l}\text { Std. Error } \\
\text { Difference }\end{array}$} & \multicolumn{2}{|c|}{$\begin{array}{c}95 \% \text { Confidence } \\
\text { Interval of the Difference }\end{array}$} \\
\hline & & & & & & & Lower & Upper \\
\hline Creativity & & 4,080 & 1 & 0,000 & 2,12903 & 0,52176 & 1,08571 & 3,17236 \\
\hline $\begin{array}{l}\text { Comprehension } \\
\text { concepts }\end{array}$ & of & 11,012 & 1 & 0,000 & 6,37097 & 0,57853 & 5,21412 & 7,52782 \\
\hline
\end{tabular}

Based on this, the hypothesis was obtained using the t-test, which was to determine the effect of the TGT type learning model on creativity and comprehension the student's concepts. Based on the independent sample t-test there was a difference in the value of creativity between the experimental class and the control class ranging from 1.08571 and 3.17236 with an average difference of 2.12903. Creativity significance value of 0,000 was less than the alpha value of 0.05 ; then $\mathrm{H}_{0}$ was rejected. This means that there was a difference in the average value of creativity between the experimental class and the control class with an error std value of 0.52176 . The difference on the value of comprehension of concept between the experimental class and the control class ranged from 5.21412 and 7.52782 with an average difference of 6.37097. The significance value of comprehension of concept was 0,000 which was less than the alpha value of 0.05 ; then $\mathrm{H}_{0}$ was rejected. This means that there was a difference in the value of the average comprehension the concept between the experimental class and the control class with an error std value of 0.57853 . Then, based on the table above, the $t_{\text {count }}$ for creativity was 4.080 and comprehension the concept was 11.012, the value were greater than $t_{\text {table }}$ where the value of $t_{\text {table }}$ was 2,000 . Based on this, it could be concluded that the average score of the two classes is different so that there was a significant positive influence on the TGT type learning model on creativity and comprehension of student's concepts in mathematics learning.

TGT cooperative learning was new learning for the student at SMP YPPSB Sangatta Utara. The learning model that has been used so far was direct learning, namely the teacher explained the material, the teacher gave an example of the problem and then the student works on the practice problem given. Learning using the TGT type allows students to work together in groups, so as to increase creativity and comprehension of student's concepts.

The results of the study were in accordance with the hypothesis that there was the influence of the TGT type learning model on creativity and comprehension of student's concepts in mathematics learning. The results of the t-test indicate a rejection of $\mathrm{H}_{0}$. The learning model was very influential on creativity and comprehension of student's concepts in mathematics learning.

The implementation of the right learning model in the learning will enhance creativity and comprehension of student's concepts. This result was in line with the research conducted by (Marnih, 2016) that the TGT cooperative learning model could improve the comprehension of student's concepts. This was also in accordance with the research conducted by Oktavia (2015), comprehension of student's concepts with the TGT cooperative learning model was higher than the comprehension of student's concepts with the STAD type cooperative learning model. This showed that comprehension of student's concepts will increase if taught using the TGT cooperative model. Another study conducted by Isjoni (2011) shows that the TGT learning model can make students with low abilities also participate actively and have an important role in their groups. Various previous studies stated that the TGT learning model had an effect on comprehension of student's concepts because with the TGT learning model it was easier for 
students to understand the student's concepts through active and enjoyable learning experiences in study groups.

\section{CONCLUSION}

The TGT learning model that has been implemented at SMP YPPSB Sangatta Utara has a significant influence on student's creativity and comprehension of concepts in mathematics learning. This was based on the results of hypothesis testing with a significant value of 0,000 where it was less than 0.05 so that the $t_{\text {count }}$ was smaller than $t_{\text {table. Therefore, the TGT learning }}$ model could be applied to enhance student's creativity and comprehension of concepts in learning mathematics at school.

\section{REFERENCES}

Agung, I., \& Yufridawati. (2013). Pengembangan Pola Kerja Harmonis dan Sinergis Antara Guru, Kepala Sekolah, dan Pengawas. Jakarta: Bestari Buana Murni.

Ainun, N. (2015). Peningkatan Kemampuan Penalaran Matematis Siswa Madrasah Aliyah Melalui Model Pembelajaran Kooperatif TEAMS GAMES TOURNAMENT, 4(1), 5563.

Baleendah, A. A., \& Rodiah, I. S. (2017). Hubungan antara kepemimpinan efektivitas guru dalam pembelajaran dengan kreativitas siswa (studi pada siswa kelas xi di madrasah aliyah assalam baleendah), 17(2), 126-137.

Basri, H. (2013). Landasan Pendidikan. Bandung: Pustaka Setia.

Ding, M. L., Piccolo, D., \& Kulm, G. (2007). Teacher Interventions In Cooperative-Learning Mathematics Classes. Journal of Educational Research, 100(3), 162-175.

Fadjar, S. (2009). Diklat Instruktur Pengembang Matematika SMA Jenjang Lanjut. Kemahiran Matematika. Yogyakarta: Departemen Pendidikan Nasional.

Hakim, A. R., \& Windayana, H. (2016). Pengaruh Penggunaan Multimedia Interaktif Dalam Pembelajaran Matematika Untuk Meningkatkan Hasil Belajar Siswa SD. EduHumaniora | Jurnal Pendidikan Dasar Kampus Cibiru, 4(2). https://doi.org/10.17509/EH.V4I2.2827.G1848

Hernawan, H. (2017). Penggunaan Aplikasi Mobile Learning Berbasis Html 5 Untuk Meningkatkan Pemahaman Mahasiswa Pada Mata Kuliah Mikrobiologi, 15(2), 645-652.

Isjoni. (2011). Pembelajaran Kooperatif, Meningkatkan Kecerdasan Komunikasi Antar Peserta Didik. Yogyakarta: Pustaka Belajar.

Isjoni. (2016). Cooperative Learning: Mengembangkan Kemampuan Belajar Berkelompok. Bandung: Alfabeta.

Mann, E. L. (2009). The Search for Mathematical Creativity: Identifying Creative Potential in Middle School Students.

Marnih. (2016). Pengaruh Model Pembelajaran Kooperatif Tipe TGT (Teams Games Tournament) Terhadap Hasil Belajar Matematika. In Prosiding Seminar Nasional Pendidikan Matematika-2 (pp. 248-253).

Mudlofir, A., \& Rusydiyah, E. F. (2017). Desain Pembelajaran Inovatif Dari Teori ke Praktik. Jakarta: Rajawali Pers.

Munandar, U. (2004). Pengembangan Kreativitas Anak Berbakat. Jakarta: Rineka Cipta.

Oktavia, I. (2015). Pengaruh Model Pembelajaran Kooperatif dan Kreativitas Belajar Siswa terhadap Pemahaman Konsep Matematika. Jurnal Kajian Pendidikan Matematika, 1(1), $16-30$.

Onal, N. (2017). Use of Interactive Whiteboard in the Mathematics Classroom : Students ' 
Perceptions within the Framework of the Technology Acceptance Model, 10(4), 67-86.

Prabawanti, E. H., Sujadi, I., \& Suyono. (2013). Eksperimentasi Model Pembelajaran Kooperatif Tipe Student Teams Achievement Division (STAD) Dan Teams Games Tournament (TGT) Pada Materi Pokok Dimensi Tiga Ditinjau Dari Aktivitas Belajar Siswa Sma Kelas X Di Kabupaten Magetan Tahun Pelajaran 2011/2012, 1(1), 34-45. Retrieved from http://www.jurnal.fkip.uns.ac.id/index.php/s2math/article/view/3480

Purnomo, Y. W. (2011). Keefektifan Model Penemuan Terbimbing Dan Cooperative Learning Pada Pembelajaran Matematika. Jurnal Kependidikan, 41(1), 37-54.

Raharjo, S. B. (2012). Evaluasi Trend Kualitas Pendidikan di Indonesia. Jurnal Penelitian Dan Evaluasi Pendidikan, 16(2), 511-532.

Retnawati, H., Kartowagiran, B., Arlinwibowo, J., \& Sulistyaningsih, E. (2017). Why are the mathematics national examination items difficult and what is teachers' strategy to overcome it? International Journal of Instruction, 10(3), 257-276. https://doi.org/10.12973/iji.2017.10317a

Richardo, R., Retno, D., \& Saputro, S. (2014). Tingkat Kreativitas Siswa dalam Memecahkan Masalah Matematika Divergen Ditinjau dari Gaya Belajar Siswa. Jurnal Elektronik Pembelajaran Matematika, 2(2), 141-151.

Sanusi, Suprapto, E., \& Apriandi, D. (2015). Pengembangan Multimedia Interaktif Sebagai Media Pembelajaran Pada Pokok Bahasan Dimensi Tiga Di Sekolah Menengah Atas (SMA). Jurnal Ilmiah Pendidikan Matematika, 3(2), 398-416.

Sharma, Y. (2014). The effects of strategy and mathematics anxiety on mathematical creativity of school students. International Electronic Journal of Mathematics Education, 9(1-2), 25-37.

Subur, J. (2013). Analisis Kreativitas Siswa Dalam Memecahkan Masalah Matematika Berdasarkan Tingkat Kemampuan Matematika Di Kelas. Jurnal Penelitian Pendidikan, 13(1).

Tarim, K. (2009). The effect of cooperative learning on preschoolers' mathematics problemsolving ability. Educational Studies in Mathematics, 72(3), 325-340.

Tiya, K. (2013). Penerapan Model Pembelajaran Kooperatif Tipe Teams Games Tournament (TGT) untuk Meningkatkan Hasil Belajar Matematika Siswa SMPN. Jurnal Pendidikan Matematika, 4(2). Retrieved from http://ejournal.undiksha.ac.id/index.php/JJPGSD/article/view/3849

Trianto. (2012). Mendesain Model Pembelajaran Inovatif-Progresif: Konsep, Landasan dan Implementasinya pada Kurikulum Tingkat Satuan Pendidikan (KTSP). Jakarta: Kencana.

Windayana, H. (2010). Pembelajaran Matematika Kontekstual Kelompok Permanen dan Tidak Permanen dalam Meningkatkan Kemampuan Penalaran dan Komunikasi Matematik Siswa Sekolah Dasar. Jurnal Pendidikan Dasar, 2(1). 